Print ISSN: 2234-3040 / Online ISSN 2234-3059

doi:10.13106/eajbm.2017.vol7.no4.27

[Review]

\title{
Qualitative Research on Decisive Issues of Halal Logistics In India
}

\author{
Rajasekhara Mouly Potluri*, Lohith Sekhar Potluri** \\ Received: May 15, 2017. Revised: August 4, 2017. Accepted: October 15, 2017.
}

\section{Abstract}

Purpose - The paper aims to explore the critical and uncover issues encountered to the supply-chain companies in launching halal based services in India.

Research design, data, and methodology - After a meticulous review of relevant literature on the halal concept and halal logistics, researchers involved in a data collection by conducting semi-structured focus group interviews. Four groups with a maximum of 5 members each have chosen from the areas of transportation, warehousing, certification, and packaging. A total of 20 questionnaires were collected by applying purposive sampling method.

Results - More than 95 percent of the chosen focus groups agreed that they know only about halal but don't have any exposure to halal logistics. The discussion has revealed that the adoption rate for halal transportation, warehousing, halal certification, and packaging is almost zero. The respondents were chosen only from transportation, warehousing, certification and packaging companies from south India which are operating throughout India. This research never attempts to be acquainted with the opinions of channel members who directly or indirectly involved in meeting customer demands.

Conclusions - This is a ground-breaking effort aimed to study the critical issues related to Indian halal logistics which is beneficial to both logistic companies as well as to the academic world.

Keywords: Halal Logistics, Transportation, Warehousing, Halal Certification, Halal Packaging, India.

JEL Classifications: L91, M0, O53.

\section{Introduction}

In view of gaining popularity for the halal concept and halal based products and services in India, the demand for halal based activity is mounting immensely not only from Muslim community but also from non-Muslim communities. Even though the term halal logistics not yet properly penetrating among the business circles in the country, there will be an enormous scope to introduce the same because of snowballing trend of awareness as well as adoption tendencies of Indians towards halal. The term halal logistics has arisen in the logistics industry in the Muslim world and

* Associate Professor, Management \& Marketing, School of Business \& Entrepreneurship, 98 Lamido Zubairu Way, Yola By-Pass, PMB 2250, YOLA, Adamawa State, American University of Nigeria, Nigeria. Tel: +91-96183-98888, E-mail: raja.potluri@aun.edu.ng,

** Graduate Student, Amrita University, Kasavanahalli, Bangalore, India. E-mail: lohithpotluri@gmail.com also slowly recognizable among the non-Muslim countries where sizeable Muslim inhabitants reside. Since 2000, Malaysian logistics industry has recognized the importance and introduced halal logistics by using the diverse sops announced by the government along with the establishment of halal hubs in every state in Malaysia. The component of halal industry can be classified into three areas, namely services, food and non-food (Ministry of Industrial and Trade, 2006a). Hence, halal logistics is labeled in one of the components in services. The development of halal industry is not only intense in Asia and Middle-East but it also expanded in Europe, North and South America including Africa. In spite of the potential growth of the halal industry in the majority of the Muslim-dominated areas, the concept of halal logistics is not actually understood by the logistic service providers. Therefore, this study is considered to be important to understand the critical and uncover issues faced by the logistic service providers in implementing halal logistics in India. 


\section{Literature Review}

\subsection{Concept of Halal}

Halal is unquestionably an Islamic nuance, a set of laws for Muslims to apply merely what is acceptable by Islam. Without any qualm, halal has received epochal economic value in the new millennium in general and Islamic world in particular. In India, only a modicum percentage of Muslims has clear knowledge on this concept but the majority believes that halal is only about meat which is not quite correct and includes all the food products, non-food products and also services. The Muslim community has to take only halal things as clearly mentioned in the Holy book of Qur'an. The concept of halal in Islam has incredibly explicit intentions like to safeguard the wholesomeness of creed; protect the Islamic way of thinking; preserve life; d) to safeguard property; e) to safeguard future generations, and f) to maintain self-respect and integrity. The Qur'an (Koran) states in Chapter 5, verse 5 , that the meat from Jews and Christians is also permissible for Muslims. Whilst the majority of Muslims would readily consume Jewish (Kosher) meat; perhaps less would feel comfortable doing so from Christians. The reason being that kosher meat follows stricter rules than in Islam and is assured to be slaughtered by first slitting the throat of the animal. Muhammad taught his followers that they have no right to kill any animal unless permitted by God. Only vegetarian animals can be slaughtered to be eaten with the exception of pigs (e.g., cows, sheep, chicken, and birds that eat no flesh) (ISRA, 2013). Halal is an Arabic word derived from the verb 'Hala' which bears the meaning of "opening a node, unwind, unscrew, unravel, untangle, disentangle, disengage, or resolving something". In Islamic concept, its definition is "things, food, or actions permitted by God's will or instruction, clean, pure, and opposed to Haram" (Al-Jallad, 2008; Malboobi \& Malboobi, 2010; Latif, 2011). Halal, by definition, means "permissible" or "allowed" in Arabic which encompasses all that is permissible to be consumed by Muslims, according to Shariah, i.e., Muslim Law. It is essentially a way of life which is not solely confined to the types of food that a Muslim is allowed to consume (Mohamed et al., 2012). Therefore, halal refers to the way of life prescribed by Almighty Allah to be followed by Muslims. This has been done by explicitly laying down parameters of what is permissible and what is not, via Quran - The Holy Book, and Hadith - The Sayings of the Prophet Mohammed, peace is upon him. Halal is a universal sign for a declaration of Islamic Shariah compliant way of life food processing to clothes designing, developing medicines, carrying trade/finance, conducting personal and social relationships and preparing cosmetics.

\subsection{Global Halal Market Size}

In the world from east to west, more than $80 \%$ of the halal trade is doing by the non-Muslim countries by making use of halal brands issued by the respective halal councils to their financial gain and become the biggest exporter status on these days (Halal Development Council, 2016a). The reason for this enormous prosperous market goes together with quality assured halal products has received greater attention from the public and the halal label has become a symbol of good quality product. As a result, along with the Muslim world, the non-Muslim community from diverse races and religious beliefs also treated this halal certified products as quality products and strongly prefer to buy which is an enormous boost to the world halal industry. The "Third One Billion" world Muslims market with a population composition of 1.6 billion along with India and China has the enormous potential for halal products and services (World Halal Summit, 2015). As per the latest research by the World Halal Forum, quoted in TIME Magazine in May of 2009, the total size of global halal food market is worth about US\$ 632 billion in 2009 and if we also include the non-Muslim consumers, the total figure will be much higher. Halal industry experts believe the size of the total global halal market (including all halal food, non-food products, and services) ranges from a minimum of US\$ 1.2 trillion to US\$ 2 trillion per annum (Halal Development Council, 2016b). Global halal food market constitutes $16 \%$ of the total global food industry at present. It is growing exponentially at the rate of $6.9 \%$ which is faster than the general food sector. It will be $17.4 \%$ in 2018 and approximately $20 \%$ by 2030 with Asia, Africa \& Europe share of $63 \%, 24 \%$, and $10 \%$ respectively. By 2018 , it will worth \$1.6 USD Trillion alone. Today, the global halal market is worth approximately USD 4 Trillion. Halal food accounts for USD 800 billion, halal finance USD 1.2 trillion, halal clothing USD 224 billion, halal pharmaceuticals USD 70 billion, halal cosmetics USD 26 billion and others. The global Muslim tourism expenditure is $\$ 126.124$ billion as in 2011 and growing at the rate of $4.79 \%$ will be $\$ 192$ billion by 2020 according to global Muslim lifestyle travel market 2012. World tourism organization states that gulf travelers spend $\$ 12$ billion ( $£ 7.7$ billion) annually on leisure travel (Halal India, 2016).

\subsection{Halal Logistics}

Both halal concept and halal logistics still in the toddler stage in the world as well in India. As said by the academicians Kamaruddin, Iberahim, and Shabudin (2012) this concept includes all the physical activities like storing and transporting which proffer the required communication to manage along the food supply chain and apply the Shariah concept along the chain. On the other hand, the core feature of halal logistics is to make sure the clear isolation 
of halal cargo with non-halal which is to avoid cross-contamination; also to align with the expectations of Muslim consumers and which in turn protect the entire supply chain's halal integrity (Ministry of Industrial \& Trade, 2006b). Thus, the most practical terminology for halal logistics is the application of Shariah law to the logistics process. There is a severe shortage of research on halal and halal logistics in the world in general and India in particular. That's why most of the input had garnered from the minimal sources available in the selected discipline for the study. Thus, halal logistics simply referred as application Shariah or Islamic law along the supply chain activities ranging from the source of supply, storage, transportation, manufacturing, handling, and distributing final products and services to the consumers. Innovations in halal such as the introduction of halal logistics is possible, as long it does not contradict with Shariah (Islamic Law) (Laldin, 2006; Zakaria, 2008; Al-Salem, 2009). Tieman (2013) comprehensively defined the term halal logistics is the practice of managing the procurement, movement, storage, and handling of materials, parts, livestock, semi-finished or finished inventory both food and non-food, and related information and documentation flows through the organization and the supply chain in compliance with the general principles of Shariah.

\subsubsection{Halal Transportation and Warehousing Issues}

Transportation and warehousing are the most crucial elements in halal logistics where there are greater chances for cross contagion amid halal and non-halal happenings. Manufacturers who are transporting halal products should use separate carriers (Lorries/trolleys) to move the stocks with halal and non-halal in nature. It is always advisable to avoid common transportation vehicles for carrying both classes of products. Tieman (2007a) stressed the notable difference between the transportation of goods with ambient and reefer. This is the distinctiveness of halal in Islam. It is a must situation to every manufacturer who involved in halal products manufacturing to maintain its halalness and it could be possible only through the introduction of the correct person in the accurate process. The same process or mode of transportation cannot use by any manufacturer to transport both halal and non-halal products. The halal veracity of the products could be questioned in case of any wrongdoing in transportation which in turn spoils the image of both manufacturer and logistic service provider. Tieman (2007b) thought that for refrigerated shipments there should be no mixing in the same container/common transportation storage of halal and severe Najis (items regarded as ritually unclean) like pork. Halal product manufacturers have to take additional actions and procedures to develop halal compliance warehousing and storage facilities to proliferate the reliability of their products. Normally, perishable goods which need refrigerated type of swift transportation and storage facilities as against non-perishables. For halal fulfillment in storage and warehousing, this is a significant and authentic reason (Tieman, 2007c). Since halal goods spend more time in storage, and storage is a place where manufacturers keep their goods before it is delivered to its destinations. Similar to the halal transport concept, halal and non-halal products can't be stored together (Ngah, Zainuddin, \& Thurasamy, 2013). Perishables like milk and its by-products, food, meat, medicines and cosmetics require diverse nature warehouse and storage facilities. Based on the nature of those products, service provider has to take precautionary measures to make available the most suitable storage and warehousing facilities to maintain the halal integrity of the stored items.

\subsubsection{Halal Certification and Packaging}

Halal product manufacturers and marketers have to intensify their efforts to acquire the certification from the World Halal Council (WHC) being a federation of halal certifying bodies worldwide after gaining international and global acceptance to their halal certification and accreditation processes. As mentioned by Shafie and Othman (2006) halal certification has issues like halal definition, issuance of halal logo by private or individual authorities, the use of Quran verses or Arabic characters on food products and premises and the weak enforcement by responsible authorities in tackling fraud logos. The World Halal Council was established in Jakarta in 1999 in order to standardize the halal certification and accreditation process among member organizations representing the different countries and nationalities worldwide. Halal certification started in the West in the mid '60s in the United States by Muslim food and technical experts which is an imperative useful tool and also a practical safety measure of Muslims living in non-Muslim societies to preserve their Muslim identity and fulfill their religious obligation (World Halal Council, 2016). Globalization is a common phenomenon in the direction of world trade today in which there is no barriers between countries. In this situation, certification like this acts as a major safety device which can prevent the importing of inferior quality products. Halal certification has to proffer authorization to manufacturers and traders to use halal logo which becomes a marketing and competitive advantage for the products marketed to the Muslim world including the Jewish communities. Halal certification has to obtain by the manufacturers separately for food and non-food products including personal care, cosmetics, utensils, fashion and clothing, shoes, logistics and the like and lately halal certification is now made mandatory to animal and poultry feeds, packaging materials such as tin cans, drums, plastic bottles and the like which are in contact with the halal quality products. Surprisingly, halal certification for drinking water is a requirement in Asian countries like Malaysia, Indonesia, Singapore and Brunei, because there are constantly decisive issues on every product which have to 
be addressed by a credible body. The world is viewing halal certification as a certificate for quality because quality is the prime concern for purchase decision of any class of consumers including for Muslims and non-Muslims.

Halal packaging has to consider the following crucial and most important decisions from the product manufacturers and marketers of halal products. Following are issues relating to halal packaging: selection of best packaging material used to contain, protect and handle goods; halal logo; product handling; human resource etc. While selecting the required packaging material both manufacturers and marketers have to be very cautiously decided on kind of material to protect the quality of products. Regarding halal logo which has capacity to single-handedly influence the buying decision, the think-tank of usage organizations has to take precautionary actions to visibly print the halal logo with the Quran verses or Arabic characters. The remarkable halal logo printed on the package of the product evidently indicate that foods sold or prepared are in line with Shariah or Islamic law and also designate that the food products are wholesome, clean and healthy. In terms of halal packaging, halal logo is doubted as there are reports that non-halal product (pork) is packaged and labeled as halal (Hong, 2007). Another notable issue in this regard, consumers are in pandemonium stage because of numerous halal logos from various countries and certifying agencies. Currently, there are about 122 active halal certifying bodies, be made up of government, firms, mosques or Islamic societies (International Halal Integrity Alliance, 2011). Apart from halal logo, product handling is also an issue for halal packaging. The halal status does not only consider the product ingredient, it also takes into account the supply chain and logistics aspects of halal food products. For example, during transportation and storage in warehouses, segregation between halal and non-halal food product must be highly practiced (Riaz \& Chaudry, 2004a). Besides, the tools to handled packaged food products must not be mixed together with the one used for non-halal products. This is done in order to avoid cross contamination (Talib et al., 2010). Food packaging must not be made from non-halal substance as it is considered najis (unclean) (Soong, 2007). Halal packaging can engage the personnel or human resource as well. This will make sure that the workers know what to do in order to avoid any halal contamination. Riaz and Chaudry (2004b) emphasizes that there should be at least one Muslim worker present during the preparation and packaging process in order to ensure maximum protection from non-halal elements. The same also reiterated by Jaafar (2011), to reduce and minimizes the possibility of cross-contamination between halal and non-halal product and avoid any human mistakes, a specialized and dedicated group of workers should handle the halal food production. These acts assertively add further confidence to the consumer and protect the halal integrity of the halal food product.

\section{Methodology}

The core purpose of the research is to explore various issues related to halal logistics like transportation, warehousing, certification, and packaging from the point of view of service providers who are operating from India. This exploratory survey has initiated by the researchers since the lack of information regarding the halal logistics in India where a significant percentage of Muslim population resides due to lack of studies. Halal logistics is a new phenomenon, for which a focus group is a common tool used (De Ruyter, 1996a; Hines, 2000; Stokes \& Bergin, 2006; Sekeran, 2007). At the same time, Sekaran and Bougie (2009a) stressed the importance of qualitative studies whenever the data has collected through personal and focus group interviews. On the basis of saturation of the topic chosen for the study, researchers have framed four focus groups from the selected four areas of the logistics viz., transportation, warehousing, certification, and packaging by taking their prior appointments. Each focus group consists of a maximum of five members who have a vast knowledge and considerable experience in their respective fields. The researchers conducted semi-structured personal interaction on the head to head with both higher and middle-level executives who were chosen with purposive sampling from the state of Andhra Pradesh. The focus group interviews and discussion primarily focused on issues related to Halal logistics mostly transportation, warehousing, Halal certification, and packaging. As emphasized by Hannabuss (1996), at the time of personal interaction with the respondents, researchers cautiously recorded and transcribed the opinions expressed which are imperatively required for better understanding and analysis later. The required data was collected for this study through primary sources particularly personal and focus group interviews which are a common tool for research discovering new phenomenon and for studies that are exploratory in nature (De Ruyter, 1996b; Sekaran \& Bougie, 2009b). Two researchers were responsible for planning and arranging meetings with focus groups, conducting discussions and recording of opinions, and finally, all the researchers involved in analyzing and recording of facts garnered from the focus groups. One researcher acts as a moderator who has also raised both open and closed-end questions. As said by Sekaran and Bougie (2009c), moderator's role is most pivotal who has more responsibility for initiating discussion with the introduction of the topic, tossing questions, leading the discussion, careful observation of proceedings of the discussion. The second researcher (note-taker) took detailed notes of these discussions. The core theme for the focus group is the halal logistics which was further divided into sub-themes like transportation, warehousing, certification and packaging, awareness and intentions of discussants on the halal concept. The collected data was then transcribed, 
analyzed and drawn conclusions mentioned in the following part of the article.

\section{Results and Discussion}

The small four discussion groups with a maximum of five participated in a thorough discussion on width and depth of the exploratory topic for the study halal logistics in India. The width of the halal logistics topic covers transportation and warehousing and in terms of depth topics like halal meaning, global halal market potentiality, certification and halal logo and packaging. Just about 95 percent of respondents from the selected four facets of halal logistics utterly expressed their lack of exposure to the research topic. They know halal means only a prayer offering before and during slaughtering of specific animals used for food but they never heard about halal logistics. All the respondents at the time of focus group interviews articulated out rightly that the implementation of halal logistics in every part of India is zilch. Most of the logistic service providers who participated in the discussion reiterated that even though significant Muslim inhabitants residing in the country, along with majority populace they are also involved in normal tendencies in their lifestyles. They are not at all particular about halal based products, actions, and things. Some of the Muslim logistic service providers said that reasons are plenty for this kind of situation. Mostly short of knowledge, poor cohesiveness, poverty of the community, lack of competitive as good demands from consumers, petite self or religious directives and government support could be the major impediments related to adopting halal oriented transportation, warehousing, certification, and packaging. Price sensitive market like India needs a lot of extra investment to adopt halal logistic services which enhance product prices and halal logistics is a novel approach, need new equipment; the cost also deemed to be considered. Indian customers are not as strong as developed customers from Europe and North America. The bandwagon effect is very common in India and most of the customers are introverts who are inconvenient to ask the merchant whether the product is halal or not; how they handle their logistics? Is the product is halal certified or not? All through the debate, the majority of the respondents emphasized that this should be reasonable and pragmatic in nature. One of the participants utterly said that safety and security should be the prime importance while loading of trucks and train bogies. Another significant factor is to define the product contagion between halal and haram and how to address and shun it. All these technical and sensitive matters which are invidious to understand for the front-line logistic service providers depict a thin line between Halal and Haram. A scanty of haram makes a product non-halal and in the case of doubt, keeps away from those kinds of products, things, and actions.

Particularly, Muslim logistic service providers said that development of all-inclusive halal based supply chain and logistics system is not possible which needs a comprehensive understanding of Shariah where a conventional halal standard only the slaughtering is covered. Non-Muslim countries like India is facing a chaotic situation in introducing halal logistics where the concept is not that much popular even in Muslim countries just like halal certifications which require a robust evolution. As said by Tieman (2011), the discussion group here is also inveterate three components as the foundation of halal logistics viz., direct contact with haram, the risk of contamination and perception of the Muslim consumers. Respondents participated in the discussion stated that if possible Muslim countries should be visualized to design the ideal halal logistics system which is also more or less suitable even to non-Muslim countries in different parts of the world. In safeguarding the halal integrity, every participant is accepted the fact a unique crystal clear documented halal procedure is required for the logistics and supply chain management. If any contamination has taken place, the document also proffers corrective mechanism to minimize the loss. Finally, all most all the logistic service providers in the selected four facets (halal transportation, halal warehousing, halal certification and halal packaging) accepted that no necessity to adopt halal logistics as of now because of no pressure from either customer or from any stakeholder of the industry. If any pressure is there from any side, they ready to introduce logistics with halal orientation, which they feel it as a crucial competitive advantage to enhance their profit picture.

\section{Conclusions}

Halal logistics is, therefore, a new area in supply chain management for which academic research is strongly needed in every part of the globe in general and India in particular. To protect the integrity of the halal is the responsibility of all the stakeholders involved in the logistics from manufacturing to the sale of the product to the consumer. The selected key disciplines in halal logistics viz., transportation, warehousing, certification, and warehousing has its unique nature to affect the halalness of the products which needs to be the conscious implementation of halal procedure and process. While designing and the introduction of halal process and procedure in logistics, designers should definitely mull over the perceptions of Muslim consumers who are residing in a non-Muslim country like India. In a multi-religious country like India, even though it is an uphill task to introduce the halal system categorically could do only with an indomitable and indefatigable commitment on two issues. One is popularizing the concept of halal among 
the Muslims where awareness is very infinitesimal, and the other is expounding about the innumerable number of benefits offered with the halal products. In this regard, the comprehensive onus is on the shoulders of Halal India and formal Islamic educational institutions at one side and local

\section{References}

Al-Jallad, N. (2008). The concepts of Al-Halal and Al-Haram in the Arab-Muslim culture: A translational and lexicographical study. Language Design, 10, 77-86.

Al-Salem, F. H. (2009). Islamic financial product innovation. International Journal of Islamic and Middle Eastern Finance and Management, 2(3), 187-200.

De Ruyter, K. (1996a). Focus versus nominal group interviews: A comparative analysis. Marketing Intelligence \& Planning, 14(6), 44-50.

De Ruyter, K. (1996b). Focus versus nominal group interviews: A comparative analysis. Marketing Intelligence \& Planning, 14(6), 44-50.

Hannabuss, S. (1996). Research interviews. New Library World, 97(5), 22-30.

Hines, T. (2000). An evaluation of two qualitative methods (focus group interviews and cognitive maps) for conducting research into entrepreneurial decision making. Qualitative Market Research: An International Journal, 3(1), 7-16.

Hong, L. (2007). NTUC Fair price to file a police report for tampering of pork packet. Channel News Asia. Retrieved February 3, 2016, from www.channelnewsasia.com/stories/singaporelocalnew s/view/309067/html

Halal Development Council (2016a). Brand Halal. Retrieved February 3, 2016 from http://www.halalpakistan.com/html/halal_market.htm

Halal India (2016). Halal Compliance Auditor Training. Retrieved February 2, 2016 from http://www.halalindia.co.in/training.html

Halal Development Council (2016b). Brand Halal. Retrieved February 3, 2016 from http://www.halalpakistan.com/html/halal_market.htm

World Halal Council (2016). About Us: Retrieved February 04, 2016 from http://www.worldhalalcouncil.com/ about-us

International Halal Integrity Alliance (2011). Halal in a Box (HIAB). Retrieved February 4, 2016, from http://www.ihialliance.org/hiab.php

Jaafar, H. S., Endut, I. R., Faisol, N., \& Omar, E. N. (2011). Innovation in logistics services: Halal
Imams who are regularly involving in Quran adages on the other side. Although the research dealt only halal logistics, there are several areas deemed to be addressed like tourism, food products, pharmaceuticals, healthcare, cosmetics, banking, textiles etc.

logistics. Proceedings of the Sixteenth International Symposium on Logistics (ISL) (pp.844-855). Retrieved February 3, 2016 from ht t p://mpra.ub.unimuenchen.de/34665/ I/MPRA_paper_34665.pdf.

Islamic Sciences and Research Academy of Australia (ISRA). (2013). The Prophet of Islam Muhammad (3rd ed.), 175.

Kamaruddin, R., Iberahim, H., \& Shabudin, A. (2012). Willingness to pay for Halal logistics: The lifestyle choice. Social and Behavioral Sciences, 50(July), 722-729.

Laldin, M. A. (2006). Islamic law: An introduction. International Islamic University, Malaysia.

Latif, M. A. (2011). Definition of halal terms and Malaysia standards and industries. The First Gulf Conference on Halal Industry and Its Services, State of Kuwait.

Malboobi, M. T., \& Malboobi, M. A. (2010). Halal concept and products derived from modern biotechnology. International Workshop for Islamic Scholars on Agri-biotechnology: Shariah Compliance, 21-28, Georgetown, Penang.

Ministry of Industry and Trade (2006a). Development of the halal industry. Third Industrial Master Plan (IMP3) 2006-2010. Retrieved February 3, 2016, from http://www.worldhalalforum.org/content/pdf/ chapter21.pdf

Ministry of Industry and Trade (2006b). Development of the halal industry. Third Industrial Master Plan (IMP3) 2006-2010. Retrieved February 3, 2016, from http://www.worldhalalforum.org/content/pdf/ chapter21.pdf

Mohamad, Z., Badruldin, B., Sharifuddin, J., Rezai, G., \& Abdullah, M. (2012). Clients' perception towards JAKIM service quality in halal certification. Journal of Islamic Marketing, 3(1), 59-71.

Ngah, Abdul Hafaz, Zainuddin, Y., \& Thurasamy, R. (2013). Adoption of halal supply chain among Malaysian halal manufacturers: An exploratory study. Social and Behavioral Sciences, 129 (2014), 388-395.

Riaz, M., \& Chaudry, M. (2004a). Halal food production. Florida: CRC Press LLC. 
Riaz, M., \& Chaudry, M. (2004b). Halal food production. Florida: CRC Press LLC.

Sekeran, U. (2007). Research methods for business: $A$ skill-building approach(4th ed.), India: Wiley.

Sekaran, U., \& Bougie, R. (2009a). Research method for business: $A$ skill-building approach(6th ed.), Singapore: Wiley.

Sekaran, U., \& Bougie, R. (2009b). Research method for business: $A$ skill-building approach(6th ed.), Singapore: Wiley.

Sekaran, U., \& Bougie, R. (2009c). Research method for business: $A$ skill-building approach(6th ed.), Singapore: Wiley.

Shafie, S., \& Othman, M. N. (2006). Halal certification: International marketing issues and Challenges. Proceedings of the International IFSAM Eighth World Congress (pp.28-30).

Soong, S. F. V. (2007). Managing Halal quality in food service industry. Unpublished Master Dissertation, University of Nevada Las Vegas, Singapore.

Strokes, D., \& Bergin, R. (2006). Methodology or Methodolatry?: An evaluation of focus groups and depth interviews. Qualitative Market Research: An International Journal, 9(1), 26-37.

Talib, Z., Zailani, S., \& Zainuddin, Y. (2010). Conceptualization on the dimensions for halal orientation for food manufacturers: A case study in the context of Malaysia. Pakistan Journal of Social Sciences, 7(2), 56-61.

Tieman, M. (2007a). The future of halal supply chain management. Halal Journal, November-December 2007, 44-46, Kuala Lumpur: KasehDia Sdn Bhd.

Tieman, M. (2007b). The future of halal supply chain management. Halal Journal, November-December 2007, 44-46, Kuala Lumpur: KasehDia Sdn Bhd.

Tieman, M. (2007c). The future of halal supply chain management. Halal Journal, November-December 2007, 44-46, Kuala Lumpur: KasehDia Sdn Bhd.

Tieman, M. (2011). The application of halal in supply chain management: In-depth interviews. Journal of Islamic Marketing, 2(2), 186-195.

Tieman, M. (2013). Establishing the principles in Halal logistics. Journal of Emerging Economies and Islamic Research, 1(1), 1-13.

World Halal Summit (2015). The global halal market stats \& trends. Retrieved October 30, 2015, from http://www.worldhalalsummit.com/the-global-halal-mark et-stats-trends

Zakaria, Z. (2008). Tapping into the world halal market: Some discussions on Malaysian laws and standards. Shariah Journal, 16, Special Edition, 603-616. 